9. Назайкинский Е. Логика музыкальной композиции. - М.: Музыка, 1982. $-319 \mathrm{c}$.

10. Осадчая С. Цикличность как ключевое свойство функционирования богослужебно-певческой традиции / Муз. мистецтво i культура. Вип. 23. - Одесса, 2016. - С. 228-237.

11. Русские мыслители. Ростов н /Д: «Феникс», 2003. - 352 с.

12. Седакова О. Вечная память. Литургическое богословие смерти. Памяти Сергея Сергеевича Аверинцева // P.:Le Messager. - Paris, 2004. Вестник русского христианского движения. № 188, 2004. - С. 52-71.

13. Ткачев А., прот. Под скальпелем природы и искусства. Православный журнал для молодежи «Отрок». - К.: «Держава»-2005.№ 5 . - С. 35 .

14. Флоренский П. Вопросы религиозного самопознания «Храмовое действо как синтез искусств»- М.: Изд-во «Москва», 2004. - 236 с.

15. Флоренский П. Иконостас - М.: Москва. - 2005. - 204 с.

16. Шмеман Александр, протоиерей. Исторический путь Православия.- М.: «Паломник», 2007. - 400 с.

DOI https://doi.org/10.30525/978-9934-26-004-9-6

\title{
МОДА ЯК СОЦІОКУЛЬТУРНИЙ ТА СЕМІОТИЧНИЙ ФЕНОМЕН
}

\author{
Калініна О. С. \\ кандидат культурологіï, \\ старший викладач кафедри культурологічних дисциплін \\ та образотворчого мистеитва \\ Харківської гуманітарно-педагогічної академії \\ м. Харків, Украӥна
}

Мода - реальний і діючий факт нашого соціального життя, що впливає на багато аспектів життєдіяльності людини і суспільства. Інтерес до здатності моди відображати специфіку суспільних трансформацій, що відбуваються стає основою побудови теоретичної системи знань про нього. Мода як науковий факт характеризує соціальні процеси, які знаходять своє виявлення у зовнішніх формах культури, модних значеннях, що вказують на цінності моди, якими наділяються ті чи інші властивості об'єктів і подій. Моді, за визначенням, властива тенденція до постійного руху та інновацій, тому вона завжди показує актуальний в певний період суспільний i культурний зміст, сутність якого 
розкривається в його соціокультурному контексті. Явище моди пов'язане iз різноманітними суспільними відносинами, у зв'язку з чим іiі осмислення проявляється у мультидисциплінарному описі сукупності різних наукових фактів.

Поняття моди, ставши об'єктом наукового пізнання, істотно трансформувалося. Ця обставина вплинула на визначення цього явища в різних значеннях i iнтерпретаціях як наукового, так i буденного характеру. Наукове знання від ненаукового відрізняють критерії, що відзначають специфіку наукового пізнання. Знання, отримані в ході наукового пізнання, є системними і обгрунтованими. Відмінні ознаки моди, як об'єкта наукового пізнання, полягають у визначенні законів іiі змін і розвитку, що відображаються в системі соціально-гуманітарних дисциплін. Мода знаходиться у полі зору філософії, соціології, економіки, політології та історії; Дуже часто поняття моди відносять до галузі виробництва одягу і її споживання, в деяких випадках відбувається змішання термінів «мода» $\mathrm{i}$ «моделювання костюма». У той же час, межа між виробництвом і споживанням розмивається все в більшій мірі, визначаючи нові тенденції в суспільстві. Однак розуміння моди набагато ширше і глибше ніж явище індустрії моди: «мода - це не тільки феномен суспільства, а й елемент соціально-виробничої системи, який накладає певний відбиток на розвиток суспільства і залишає свій слід в динаміці і напрямку розвитку кожної з його сфер» [1, с. 284]. Вироблення i теоретична систематизація об'єктивних знань про моду є основною ознакою наукового підходу до осмислення даного феномена. Так, А.Б. Гофман вибудовує теоретичну модель моди, яка дозволяє «уявити моду у вигляді ідеалізованого, або ідеального, об'єкту, що не є тотожнім моді як об'єкта емпіричного спостереження, що володіє складною структурою і складається із сукупності взаємопов'язаних елементів приватних ідеальних об'єктів» [2, с. 10]. У широкому сенсі мода визначається як «існуюче в певний період і загальновизнане на даному етапі відношення до зовнішніх форм культури» [2, с. 11].

Не менш суспільно важливою $\epsilon$ семіотична природа моди, розповсюдженою точкою зору $є$ та, що стверджує, мода - це засіб ідентифікації, який дозволяє сучасній людині співвідносити себе із схожими на себе та протиставити іншим. Відомо також, що мода може маніфестувати певні ідеї, інформувати публіку про те чи інше. Вважається, що мода робить людину цікавим та привабливим. Іноді моду можна визначити як культурний механізм оновлення.

Дослідження показують, що мода створює реальність в якій людина може відчувати себе так, як йому хочеться себе відчувати, стає тим, ким він бажає бути. Одягнувши модне плаття чи костюм, узявши дорогий та трендовий мобільний телефон, сівши за руль потужного джипу, людина 28 
стає вже іншою - красивою, цікавою, сильною та багатою. Таким чином, щоб поставити себе у центр уваги інших людей, треба з себе зробити взірець, ідеал, цінність, замість себе «послати» важливий для інших персонаж. Найпростіше це зробити за допомогою мистецтва конструювання особливої реальності, моди. Ставши самостійною реальністю, мистецтво у широкому сенсі сприяло тому, що людина навчилася бачити і переживати себе як особливий твір, грати різні ролі (красивої жінки, успішної людини і т. д.). Все це дозволяє йому розраховувати на увагу інших, і не просто увагу, а потрібне відношення до себе - подив, захоплення, заздрість і т.д. [3, с. 104]

\title{
Література:
}

1. Алексеенко Л.В. Социология моды: классический социологический дискурс о моде. Актуальные проблемы гуманитарных и естественных наук. 2012. № 6. С. 284-288.

2. Гофман А.Б. Мода и люди. Новая теория моды и модного поведения.- М.: Книжный ддом «Университет», 2013. 228 с.

3. Розин В.М. Мода как культурно-семиотический и психологический феномен. Культурология: дайджест/Рос. акад. Наук, ин-т науч. информ.- М., 2010. 225 с.

4. Тканко 3. Мода в Україні XX століття. - Л. : Артос, 2015. 236 с.

DOI https://doi.org/10.30525/978-9934-26-004-9-7

\section{КІНЕЦЬ ІСТОРІЇ МИСТЕЦТВА ТА КІНЕЦЬ КРИТИКИ ЯК ТЕОРЕТИЧНІ СЮЖЕТИ КІНЦЯ ХХ І ПОЧАТКУ ХХІ СТОЛІТТЯ}

\author{
Калугер А. О. \\ асистент кафедри історії мистеитвва \\ Київського національного університету імені Тараса Шевченка \\ м. Київ, Украӥна
}

Особливої актуальності теоретичні сюжети «кінця історії мистецтва» набули в 1980 році після публікації праці Ханса Белтінга «Кінець історії мистецтва?» Вже тоді ним продублювалася теза щодо кінця класичної історії мистецтва і перетворення ії на історії образів. Наступні 40 років академічне мистецтвознавство було обернене в бік перетворення традиційної історії мистецтва на візуальні студії, дослідження образної 